\title{
The Effect of Insulin on Renal Handling of Sodium, Potassium, Calcium, and Phosphate in Man
}

\author{
Ralph A. DeFronzo, C. Robert Cooke, Reubin Andres, \\ Gerald R. Faloona, and Paul J. Davis \\ From the Clinical Physiology Branch, Gerontology Research Center, \\ National Institute of Child Health and Human Development, National \\ Institutes of Health, Baltimore City Hospitals, Baltimore, 21224; \\ Department of Medicine, The Johns Hopkins University School of \\ Medicine, Baltimore, 21205; Veterans Administration Hospital and \\ Department of Biochemistry, University of Texas Health Science Center, \\ Dallas, Texas 75201; and the Department of Medicine, Baltimore City \\ Hospitals, Baltimore, Maryland 21224
}

A BSTRACT The effects of insulin on the renal handling of sodium, potassium, calcium, and phosphate were studied in man while maintaining the blood glucose concentration at the fasting level by negative feedback servocontrol of a variable glucose infusion. In studies on six water-loaded normal subjects in a steady state of water diuresis, insulin was administered i.v. to raise the plasma insulin concentration to between 98 and $193 \mu \mathrm{U} / \mathrm{ml}$ and infused at a constant rate of 2 $\mathrm{mU} / \mathrm{kg}$ body weight per min over a total period of 120 min. The blood glucose concentration was not significantly altered, and there was no change in the filtered load of glucose; glomerular filtration rate $\left(\mathrm{C}_{\mathrm{Ix}}\right)$ and renal plasma flow ( $\mathrm{C}_{\mathrm{PAH}}$ ) were unchanged. Urinary sodium excretion $\left(\mathrm{U}_{\mathrm{xa}} \mathrm{V}\right)$ decreased from $401 \pm 46$ (SEM) to $213 \pm 18 \mu \mathrm{eq} / \mathrm{min}$ during insulin administration, the change becoming significant $(P<0.02)$ within the $30-60-\mathrm{min}$ collection period. Free water clearance $\left(\mathrm{C}_{\mathrm{H}_{2} \mathrm{O}}\right)$ increased from $10.6 \pm 0.6$ to $13 \pm 0.5 \mathrm{ml} / \mathrm{min}(P$ $<0.025)$; osmolar clearance decreased and urine flow was unchanged. There was no change in plasma aldosterone concentration, which was low throughout the studies, and a slight reduction was observed in plasma glucagon concentration.

This work was presented in part at the eastern section Meeting of the American Federation for Clinical Research, Boston, Mass., 12 January 1974.

Dr. DeFronzo's current address is the Renal Division, Gates Pavilion, Hospital of the University of Pennsylvania, Philadelphia, $\mathrm{Pa}$.

Reccized for publication 9 August 1974 and in rezised form 2 December 1974.
Urinary potassium $\left(\mathrm{U}_{\mathrm{K}} \mathrm{V}\right)$ and phosphate $\left(\mathrm{U}_{\mathrm{P}} \mathrm{V}\right)$ excretion were also both decreased during insulin administration; $\mathrm{U}_{\mathrm{K}} \mathrm{V}$ decreased from $66 \pm 9$ to $21 \pm 1 \mu \mathrm{eq} / \mathrm{min}$ $(P<0.005)$, and $\mathrm{U}_{\mathrm{PV}}$ decreased from $504 \pm 93$ to 230 $\pm 43 \mu \mathrm{g} / \mathrm{min}(P<0.01)$. The change in $\mathrm{U}_{\mathrm{K}} \mathrm{V}$ was associated with a significant reduction in plasma potassium concentration. There was also a statistically significant but small reduction in plasma phosphate concentration which was not considered sufficient alone to account for the large reduction in $U_{P} V$. Urinary calcium excretion $\left(\mathrm{U}_{\mathrm{Ca}} \mathrm{V}\right)$ increased from $126 \pm 24$ to $200 \pm 17 \mu \mathrm{g} / \mathrm{min}(P<0.01)$.

These studies demonstrate a reduction in $\mathrm{U}_{\mathrm{Na}} \mathrm{V}$ associated with insulin administration that occurs in the absence of changes in the filtered load of glucose, glomerular filtration rate, renal blood flow, and plasma aldosterone concentration. The effect of insulin on $\mathrm{C}_{\mathbf{H}: \mathbf{O}}$ suggests that insulin's effect on sodium excretion is due to enhancement of sodium reabsorption in the diluting segment of the distal nephron.

\section{INTRODUCTION}

In vitro studies on amphibian epithelia (1-4) and on isolated perfused dog kidney (5) have suggested an effect of insulin on sodium transport. A simliar effect of insulin on renal tubular sodium transport in man, however, has not been previously demonstrated. The studies of Atchley, Loeb, Richards, Benedict, and Driscoll (6) demonstrated a marked increase in sodium excretion after abrupt withdrawal of insulin therapy in patients

The Journal of Clinical Investigation Volume 55 April 1975·845-855 
with diabetes mellitus; similar observations have been made recently by Saudek, Boulter, Knoop, and Arky (7). Reinstitution of insulin therapy in these studies resulted in a marked reduction in sodium excretion. However, changes in the filtered load of glucose, extracellular fluid volume, glomerular filtration rate (GFR), and renal blood flow, as well as possible changes in aldosterone secretion due to changes in fluid volume, may have conspired to alter sodium excretion in these patients. In a more adequately controlled study, Miller and Bogdonoff (8) observed a reduction in urinary sodium excretion after insulin administration to subjects undergoing either a solute (glucose) diuresis or a water diuresis.

Studies carried out on fasted obese subjects have shown that refeeding of carbohydrate, with resultant stimulation of insulin secretion, results in marked retention of sodium $(9,10)$. The mechanism of sodium retention associated with carbohydrate refeeding has not been elucidated (11-19). It cannot be attributed to persistence of increased aldosterone secretion or to reduced GFR $(15,18,20)$. Plasma glucagon concentration increases during fasting and decreases during refeeding $(21,22)$. Since glucagon is known to have natriuretic properties (23-26), sodium retention during refeeding could be related, at least in part, to a reduction in plasma glucagon concentration. However, carbohydrate-stimulated insulin secretion is also temporally related to sodium retention, and one may reasonably raise the question whether insulin plays a role in this phenomenon.

To determine the role of insulin on renal tubular sodium reabsorption in the absence of associated changes in the filtered load of glucose or glucose excretion, we administered insulin i.v. to six normal volunteer subjects while maintaining the blood glucose concentration at the fasting level by a negative feedback servocontrol mechanism (27) which allows the frequent adjustment of a variable glucose infusion to maintain constant blood glucose concentration. Additional factors acting on renal tubular sodium reabsorption-GFR, renal blood flow, plasma aldosterone, and glucagon concentration-were monitored to more clearly define the mechanism of any observed changes in sodium excretion. Effects of insulin administration on potassium, calcium, phosphate, and total solute excretion were also investigated in these studies.

1 Abbreviations used in this paper: $\mathrm{C}_{\mathrm{H}: \mathrm{o}}$, free water clearance; $C_{I N}$, insulin clearance; $C_{N A} / C_{I N} \times 100$, fractional sodium excretion; $\mathrm{C}_{\mathrm{Na}} \mathrm{V}$, mean sodium excretion; $\mathrm{C}_{\mathrm{osm}}$, osmolar clearance; $\mathrm{C}_{\mathrm{PAH}}$, PAH clearance; GFR, glomerular filtration rate; $\mathrm{PAH}$, para-aminohippurate; $\mathrm{U}_{\mathrm{Ca}} \mathrm{V}$, urinary calcium excretion; $U_{K} V$, urinary potassium excretion; $U_{\mathrm{Na}} V$, mean sodium excretion; $\mathrm{U}_{\mathrm{P}} \mathrm{V}$, urinary phosphate excretion; $\mathrm{V}$, urine volume.

\section{METHODS}

Insulin infusion studies. Six normal male volunteers ranging in age from 24 to $37 \mathrm{yr}$ were studied. All responded normally to an oral glucose tolerance test (28). None of the subjects weighed more than $20 \%$ above the middle of the weight range for medium frame subjects. ${ }^{2}$ During the 4 days before the study, all subjects consumed at least $200 \mathrm{~g}$ of carbohydrate daily with no dietary restriction of sodium. To insure high sodium intake during this 4-day period, the dietary intake of each subject was supplemented with $154 \mathrm{meq}$ of sodium chloride daily. Subjects were fasted after 11 p.m. of the evening preceding the studies, and after arising at $7 \mathrm{a}$.m. on the morning of the studies they drank $500 \mathrm{ml}$ of water before reporting to the metabolic unit where an additional water load $(20 \mathrm{ml} / \mathrm{kg}$ body weight) was administered orally at 8 a.m. Priming doses of inulin $(40 \mathrm{mg} / \mathrm{kg}$ body weight) and para-aminohippurate (PAH)

(12 $\mathrm{mg} / \mathrm{kg}$ body weight) were administered i.v. via a polyethylene catheter inserted into an antecubital vein in the right arm.

Sustaining infusions of inulin and $\mathrm{PAH}$ in $0.9 \%$ sodium chloride were administered at a rate of $0.8 \mathrm{ml} / \mathrm{min}$ throughout the studies. The subjects remained supine except to void, and the volume of each voiding was replaced by water taken orally to achieve a steady state of water diuresis. After a 45-min equilibration period of sustained water diuresis and of inulin and $\mathrm{PAH}$ infusion, four consecutive 30 -min urine volumes were collected. Arterial blood samples were obtained at the beginning of the clearance studies and at the end of each 30 -min clearance period.

After the fourth 30 -min control period a priming dose of insulin ( $40 \mathrm{mU} / \mathrm{kg}$ body weight) was administered over a period of $10 \mathrm{~min}$ via a second polyethylene catheter positioned in a left antecubital vein and a sustaining infusion of insulin was begun at a rate of $2 \mathrm{mU} / \mathrm{kg}$ weight per min. Concomitantly, an i.v. infusion of $20 \%$ glucose was begun and arterial blood samples were obtained at 5-min intervals through a polyethylene catheter in a brachial artery for determination of blood glucose concentration. Rapid determination of arterial blood glucose concentration permitted frequent, prompt adjustment of the glucose infusion rate for the purpose of maintaining the subjects' blood glucose concentration at the preinsulin fasting level (28). Blood and urine samples were collected every $30 \mathrm{~min}$ during the succeeding $2 \mathrm{~h}$ as in the preinsulin control period. The volume of blood samples collected in the studies was promptly replaced with equal volumes of normal saline.

Control ziater diuresis studics. Two subjects (R. D. and P. D.) were restudied under similar conditions of sustained water diuresis and recumbency, but without insulin administration. Dietary preparation and sodium loading before the studies, the time of arising, and the time of water loading on the day of the studies were the same as those in the insulin infusion protocol. Total duration of the control water diuresis studies was also $240 \mathrm{~min}$; during this period blood and urine samples were collected as in the insulin infusion studies. Endogenous creatinine clearance was used as an index of GFR.

Analytical methods. Plasma and urine sodium and potassium concentrations were determined by AutoAnalyzer flame photometry Technicon Instruments Corp., Tarrytown, N. Y.). Plasma and urine calcium concentrations were measured by atomic absorption spectrometry (29), and plasma and urine phosphate were determined by the method

2 Metropolitan Life Insurance Company Tables, 1959. 
of Fiske and Subbarow (30) adapted to the AutoAnalyzer. Osmolality was measured by freezing point depression using a Fiske osmometer (Fiske Associates Inc., Uxbridge, Mass). Creatinine and PAH concentrations were determined by AutoAnalyzer techniques $(31,32)$. Insulin concentrations in plasma and urine were quantitated by the method of Walser, Davidson, and Orloff (33). Blood glucose concentration was determined by an automated ferricyanide method (Technicon Instruments Corp.). Plasma insulin concentration was measured by double antibody radioimmunoassay (34), automated to the Micromedic (Micromedic Systems, Inc., Philadelphia, Pa.). Plasma aldosterone concentration was determined by a modification of radioimmunoassay techniques, as previously described (35), and plasma glucagon concentration was measured by radioimmunoassay (36).

In the statistical analysis of the data, observations from the four control clearance periods before insulin administration in each subject were averaged and compared with the average of the observations from the final three clearance periods during insulin administration (paired $t$ test). Data from the initial 30 -min period of insulin administration were omitted because of the temporal delay in insulin effect. In addition, the averages for the group of six subjects were analyzed by $t$ test for evidence of an effect of insulin.

\section{RESULTS}

\section{Insulin infusion studies}

Plasma insulin and blood glucose concentration; inulin and PAH clearances. Data from each of the six subjects are shown in Table $I$ as the mean ( \pm SEM) of four control periods and the final three periods of insulin administration. Mean plasma insulin concentration in the six subjects during the control period ranged from 6 to $21 \mu \mathrm{U} / \mathrm{ml}$. The steady-state plasma levels achieved after the priming dose of insulin ranged from 98 to $193 \mu \mathrm{U} / \mathrm{ml}$. Despite this increase in plasma insulin concentration, the blood glucose concentration was not significantly altered, remaining within 96-99\% of the control level as a result of glucose administration. Under steady-state conditions of euglycemia, the amount of glucose metabolized equals the quantity of glucose infused, and ranged from 5.1 to $8.1 \mathrm{mg}$ glucose per kilogram body weight per minute.

There was no change in inulin clearance $\left(C_{1 N}\right)$ and,

TABLE I

Effect of Increased Plasma Insulin Concentration on Blood Glucose Concentration, Metabolized and Filtered Glucose, Inulin, and PAH Clearance

\begin{tabular}{|c|c|c|c|c|c|c|c|c|}
\hline Subject & Period & $\begin{array}{l}\text { Plasma } \\
\text { insulin }\end{array}$ & $\begin{array}{l}\text { Blood } \\
\text { glucose }\end{array}$ & $\begin{array}{c}\text { Glucose } \\
\text { metabolized }\end{array}$ & $\begin{array}{l}\text { Inulin } \\
\text { clearance }\end{array}$ & $\begin{array}{l}\text { Filtered } \\
\text { glucose }\end{array}$ & $\begin{array}{c}\text { PAH } \\
\text { clearance }\end{array}$ & $\begin{array}{l}\text { Filtration } \\
\text { fraction }\end{array}$ \\
\hline \multirow{3}{*}{ L. B. } & & $\mu C / m l$ & $\mathrm{mg} / 100 \mathrm{ml}$ & $\mathrm{mg} / \mathrm{kg} / \mathrm{min}$ & $\mathrm{ml} / \mathrm{min}$ & $m g / m i n$ & ml'min & $m l / m i n$ \\
\hline & Control & $13 \pm 1$ & $90 \pm 1$ & & $80 \pm 3$ & 72 & $586 \pm 35$ & $0.14 \pm 0.004$ \\
\hline & Insulin & $193 \pm 5$ & $86 \pm 1$ & 7.9 & $71 \pm 2$ & 61 & $628 \pm 41$ & $0.11 \pm 0.008$ \\
\hline \multirow{2}{*}{ R. M. } & Control & $6 \pm 1$ & $100 \pm 1$ & & $106 \pm 3$ & 106 & $711 \pm 39$ & $0.15 \pm 0.007$ \\
\hline & Insulin & $116 \pm 8$ & $96 \pm 1$ & 8.1 & $100 \pm 6$ & 96 & $795 \pm 38$ & $0.12 \pm 0.010$ \\
\hline \multirow{2}{*}{ H. W. } & Control & $6 \pm 1$ & $92 \pm 1$ & & $104 \pm 2$ & 98 & $897 \pm 86$ & $0.12 \pm 0.011$ \\
\hline & Insulin & $98 \pm 7$ & $90 \pm 1$ & 6.7 & $121 \pm 4$ & 108 & $936 \pm 90$ & $0.13 \pm 0.010$ \\
\hline \multirow{2}{*}{ G. B. } & Control & $9 \pm 1$ & $86 \pm 1$ & & $113 \pm 2$ & 97 & $614 \pm 40$ & $0.20 \pm 0.007$ \\
\hline & Insulin & $136 \pm 9$ & $82 \pm 1$ & 7.4 & $125 \pm 6$ & 103 & $686 \pm 31$ & $0.18 \pm 0.010$ \\
\hline \multirow{2}{*}{ R. D. } & Control & $16 \pm 2$ & $95 \pm 1$ & & $110 \pm 7$ & 105 & $669 \pm 13$ & $0.16 \pm 0.007$ \\
\hline & Insulin & $175 \pm 7$ & $95 \pm 1$ & 5.2 & $117 \pm 3$ & 111 & $629 \pm 36$ & $0.19 \pm 0.010$ \\
\hline \multirow{2}{*}{ P. D. } & Control & $21 \pm 4$ & $92 \pm 1$ & & $109 \pm 6$ & 100 & $509 \pm 22$ & $0.22 \pm 0.010$ \\
\hline & Insulin & $173 \pm 6$ & $91 \pm 1$ & 5.1 & $103 \pm 1$ & 94 & $492 \pm 5$ & $0.21 \pm 0.003$ \\
\hline \multirow{2}{*}{ Mean \pm SEM } & Control & $12 \pm 2$ & $92 \pm 2$ & & $104 \pm 5$ & $96 \pm 5$ & $664 \pm 54$ & $0.17 \pm 0.020$ \\
\hline & Insulin & $\begin{array}{c}149 \pm 15 \\
P<0.001\end{array}$ & $90 \pm 2$ & $6.7 \pm 0.5$ & $106 \pm 8$ & $96 \pm 7$ & $694 \pm 62$ & $0.16 \pm 0.020$ \\
\hline
\end{tabular}

Since the blood glucose concentration was maintained constant, the amount of glucose infused to maintain euglycemia must equal the amount of glucose metabolized. 
TABLE II

Effect of Insulin on Plasma Sodium Concentration, Sodium Excretion, and Sodium Clearance

\begin{tabular}{cccccc}
\hline Subject & Period & Plasma sodium & $\mathrm{U} \mathrm{UaV}$ & $\mathrm{C}_{\mathrm{Na}}$ & $\mathrm{C}_{\mathrm{Na}} / \mathrm{C}_{\mathrm{IN}} \times 100$ \\
\hline & Control & $139 \pm 0.2$ & $319 \pm 21$ & $2.29 \pm 0.15$ & $2.97 \pm 0.28$ \\
L. B. & Insulin & $140 \pm 0.2$ & $223 \pm 23$ & $1.59 \pm 0.16$ & $2.27 \pm 0.19$ \\
& Control & $145 \pm 0.5$ & $446 \pm 55$ & $3.07 \pm 0.37$ & $2.85 \pm 0.27$ \\
R. M. & Insulin & $144 \pm 0.6$ & $187 \pm 2$ & $1.30 \pm 0.01$ & $1.39 \pm 0.05$ \\
& Control & $147 \pm 0.2$ & $598 \pm 19$ & $4.07 \pm 0.12$ & $3.95 \pm 0.15$ \\
H. W. & Insulin & $146 \pm 0.4$ & $247 \pm 35$ & $1.68 \pm 0.24$ & $1.42 \pm 0.23$ \\
& Control & $138 \pm 0.3$ & $324 \pm 13$ & $2.35 \pm 0.10$ & $2.00 \pm 0.01$ \\
G. B. & Insulin & $137 \pm 0.5$ & $148 \pm 16$ & $1.08 \pm 0.12$ & $0.90 \pm 0.12$ \\
& Control & $142 \pm 0.5$ & $409 \pm 14$ & $2.87 \pm 0.10$ & $2.62 \pm 0.10$ \\
R. D. & Insulin & $141 \pm 0.6$ & $273 \pm 37$ & $1.93 \pm 0.22$ & $1.67 \pm 0.21$ \\
& Control & $140 \pm 0.2$ & $308 \pm 15$ & $2.20 \pm 0.11$ & $2.03 \pm 0.09$ \\
P. D. & Insulin & $139 \pm 0.2$ & $201 \pm 6$ & $1.45 \pm 0.05$ & $1.40 \pm 0.05$ \\
& Control & $142 \pm 1.0$ & $401 \pm 46$ & $2.81 \pm 0.29$ & $2.74 \pm 0.29$ \\
Mean & Insulin & $141 \pm 1.0$ & $213 \pm 18$ & $1.51 \pm 0.12$ & $1.51 \pm 0.18$ \\
& & & $(P<0.01)$ & $(P<0.005)$ & $(P<0.01)$ \\
\hline & & & & &
\end{tabular}

since the blood glucose concentration was constant, there was no change in filtered load of glucose. All urine samples were free of glucose as determined by the glu-

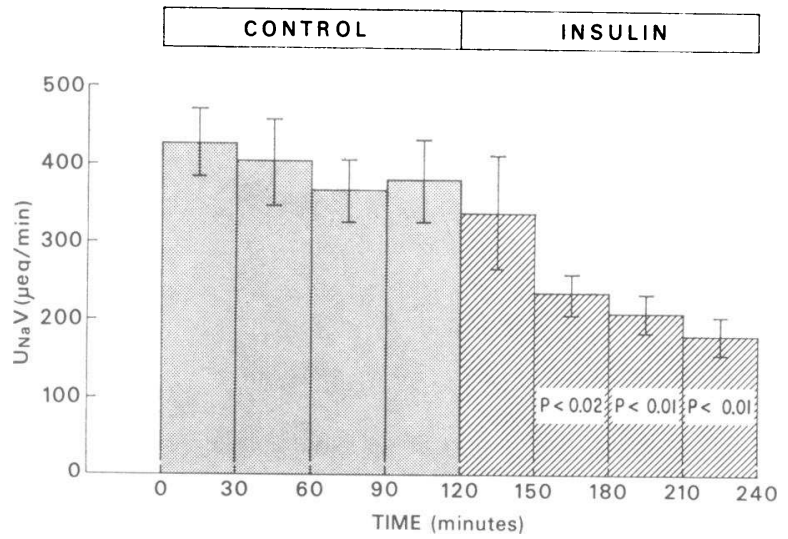

FIGURE 1 Time-course of fall in urinary sodium excretion $\left(\mathrm{U}_{\mathrm{Na}} \mathrm{V}\right)$ during insulin administration in man. Data represent mean values of six subjects. Plasma insulin concentrations during insulin infusion were constant for each subject (range for the group was 98-193 $\mu \mathrm{U} / \mathrm{ml}$ ). Steady-state water diuresis was maintained throughout control and insulin administration periods. cose oxidase reaction (Labstix, Ames Co. Div. of Miles Lab, Inc., Elkhart, Ind.). PAH clearance ( $\left.\mathrm{C}_{\mathrm{PAB}}\right)$ and filtration fraction were also unchanged during insulin administration as compared to the control period.

Plasma and urine sodium. As shown in Table II, there was no significant change in plasma sodium concentration during insulin infusion. The mean plasma sodium concentration for the six subjects was $142 \pm 1$ $\mathrm{meq} /$ liter in the control period and $141 \pm 1 \mathrm{meq} /$ liters during insulin administration. However, mean sodium excretion $\left(\mathrm{U}_{\mathrm{NaV}}\right)$ and sodium clearance $\left(\mathrm{C}_{\mathrm{Na}}\right)$ for the group were both significantly reduced during insulin administration as compared to the control period. $\mathrm{U}_{\mathrm{Na}} \mathrm{V}$ fell from $401 \pm 46$ to $213 \pm 18 \mu \mathrm{eq} / \mathrm{min}(P<0.01)$, and $\mathrm{C}_{\mathrm{Na}}$ decreased from $2.81 \pm 0.29$ to $1.51 \pm 0.12 \mathrm{ml} / \mathrm{min}(P$ $<0.005)$. Fractional sodium excretion $\left(\mathrm{C}_{\mathrm{Na}} / \mathrm{C}_{\mathrm{IN}} \times 100\right)$ was also reduced (from $2.74 \pm 0.29$ to $1.51 \pm 0.18 \mathrm{ml}$ / $\min , P<0.01)$. The time relationship of insulin administration to $\mathrm{U}_{\mathrm{Na}} \mathrm{V}$ is shown in Fig. 1. The effect of insulin was significant $(P<0.02)$ during the $30-60$ min period after the infusion of insulin was begun, and was more pronounced during the 60-90- and 90120 -min collection periods. The difference between the mean $\mathrm{U}_{\mathrm{Na}} \mathrm{V}$ in the four control period collections and 
TABLE III

Effect of Insulin on Plasma Concentration and Crinary Excretion Rate of Potassium, Calcium, and Phosphate

\begin{tabular}{|c|c|c|c|c|c|c|c|}
\hline Subject & Period & Plasma $\mathrm{K}$ & Plasma Ca & Plasma P & $\mathrm{U}_{\mathrm{K}} \mathrm{V}$ & $\mathrm{UcaV}$ & $\mathrm{UPV}_{\mathrm{P}} \mathrm{V}$ \\
\hline \multirow{3}{*}{ L. B. } & & meq/liter & $\mathrm{mg} / 100 \mathrm{ml}$ & $\mathrm{mg} / 100 \mathrm{ml}$ & $\mu e q / \min$ & $\mu g / \min$ & $\mu g / \min$ \\
\hline & Control & $4.0 \pm 0.01$ & $9.1 \pm 0.1$ & $2.6 \pm 0.02$ & $61 \pm 10$ & $90 \pm 6$ & $433 \pm 24$ \\
\hline & Insulin & $3.4 \pm 0.11$ & $8.9 \pm 0.1$ & $2.0 \pm 0.03$ & $21 \pm 3$ & $153 \pm 41$ & $183 \pm 31$ \\
\hline \multirow{2}{*}{ R. M. } & Control & $4.0 \pm 0.02$ & $8.6 \pm 0.2$ & $2.6 \pm 0.06$ & $69 \pm 6$ & $97 \pm 2$ & $724 \pm 41$ \\
\hline & Insulin & $3.3 \pm 0.11$ & $9.1 \pm 0.1$ & $2.7 \pm 0.01$ & $18 \pm 1$ & $154 \pm 10$ & $397 \pm 10$ \\
\hline \multirow{2}{*}{ H. II. } & Control & $3.8 \pm 0.05$ & $9.1 \pm 0.2$ & $2.8 \pm 0.06$ & $51 \pm 6$ & $242 \pm 9$ & $764 \pm 32$ \\
\hline & Insulin & $3.2 \pm 0.06$ & $9.2+0.2$ & $2.3 \pm 0.06$ & $23 \pm 3$ & $257 \pm 21$ & $208 \pm 9$ \\
\hline \multirow{2}{*}{ G. B. } & Control & $3.7 \pm 0.01$ & $8.7 \pm 0.1$ & $2.0 \pm 0.02$ & $108 \pm 3$ & $79 \pm 5$ & $253 \pm 28$ \\
\hline & Insulin & $3.1 \pm 0.09$ & $8.9 \pm 0.3$ & $1.8 \pm 0.03$ & $25 \pm 3$ & $193 \pm 20$ & $109 \pm 5$ \\
\hline \multirow{2}{*}{ R. D. } & Control & $3.7 \pm 0.03$ & $9.4 \pm 0.1$ & $2.5 \pm 0.01$ & $50 \pm 4$ & $129 \pm 8$ & $599 \pm 14$ \\
\hline & Insulin & $3.1 \pm 0.08$ & $9.2 \pm 0.1$ & $2.0 \pm 0.03$ & $20 \pm 3$ & $252 \pm 21$ & $317 \pm 42$ \\
\hline \multirow{2}{*}{ P. D. } & Control & $3.7 \pm 0.05$ & $9.3 \pm 0.1$ & $2.5 \pm 0.05$ & $57 \pm 7$ & $118 \pm 5$ & $249 \pm 30$ \\
\hline & Insulin & $3.0 \pm 0.10$ & $9.1 \pm 0.1$ & $2.1 \pm 0.03$ & $18 \pm 3$ & $191 \pm 8$ & $167 \pm 19$ \\
\hline \multirow{2}{*}{ Mean \pm SEM } & Control & $3.8 \pm 0.06$ & $9.0 \pm 0.1$ & $2.5 \pm 0.10$ & $66 \pm 9$ & $126 \pm 24$ & $504 \pm 93$ \\
\hline & Insulin & $\begin{array}{c}3.2 \pm 0.06 \\
(P<0.001)\end{array}$ & $9.1 \pm 0.1$ & $\begin{array}{c}2.2 \pm 0.10 \\
(P<0.05)\end{array}$ & $\begin{array}{c}21 \pm 1 \\
(P<0.005)\end{array}$ & $\begin{array}{c}200 \pm 17 \\
(P<0.01)\end{array}$ & $\begin{array}{c}230 \pm 43 \\
(P<0.01)\end{array}$ \\
\hline
\end{tabular}

that in the final three periods of insulin administration was also significant for each subject.

Plasma and urine potassium, calcium, and phosphate. Plasma potassium concentration decreased significantly during insulin administration, as shown in Table III. Mean plasma potassium level in the final control period was $3.8 \pm 0.06 \mathrm{meq} / \mathrm{liter}$ and decreased to $3.1 \pm 0.07 \mathrm{meq} /$ liter in the final period of insulin administration (data not shown). This reduction in plasma potassium concentration was accompanied by a decrease in urinary potassium excretion $\left(\mathrm{U}_{\mathrm{K}} \mathrm{V}\right.$ ) from $66 \pm 9 \mu \mathrm{eq} / \mathrm{min}$ in the control period to $21 \pm 1 \mu \mathrm{eq} / \mathrm{min}$ during insulin administration $(P<0.005)$ (Table III). Plasma calcium concentration was unchanged by insulin. However, urinary calcium excretion $\left(\mathrm{Uca}_{\mathrm{a}}\right.$ ) increased from $126 \pm 24$ to $200 \pm 17 \mu \mathrm{g} / \mathrm{min}(P<0.01)$, and calcium clearance increased from $1.4 \pm 0.3$ to $2.2 \pm 0.2 \mathrm{ml} / \mathrm{min} \quad(P<0.01)$ during insulin infusion. The administration of insulin was associated with a small but significant reduction in plasma phosphate concentration from $2.5 \pm 0.10$ to $2.2 \pm 0.10 \mathrm{mg} / 100 \mathrm{ml}(P<0.05)$. Plasma phosphate did not decrease in one subject (R. M.). Urinary phosphate excretion $\left(U_{P} V\right.$ ) decreased from $504 \pm 93$ to 230 $\pm 43 \mu \mathrm{g} / \mathrm{min}(P<0.01)$, and phosphate clearance was reduced from $21 \pm 3$ to $11 \pm 2 \mathrm{ml} / \mathrm{min}(P<0.02)$. All subjects, including R. M., showed decreased $U_{P} V$ and phosphate clearance.

Plasma and urine osmolality. There was no change in plasma osmolality associated with insulin administration (Table IV). Urine osmolality was significantly reduced $(P<0.025)$, urine flow rate was unchanged. and osmolar clearance ( $C_{\text {osm }}$ ) decreased from $4.9 \pm 0.5$ to $3.3 \pm 0.4 \mathrm{ml} / \mathrm{min}(P<0.01)$. The reduction in $\mathrm{C}_{\mathrm{osm}}$ is accounted for by the fall in $\mathrm{C}_{\mathrm{xa}}$. Free water clearance $\left(\mathrm{C}_{\mathrm{H}_{2} \mathrm{O}}\right)$ increased from $10.6 \pm 0.6$ to $13.0 \pm 0.5 \mathrm{ml} / \mathrm{min}$ $(P<0.02)$ during the period of insulin infusion and $\mathrm{C}_{\mathrm{H}_{2} \mathrm{O}} / \mathrm{C}_{\mathrm{IN}} \times 100$ increased from $10.4 \pm 0.9$ to $12.8 \pm 0.8$ $\mathrm{ml} / \mathrm{min}(P<0.01) . \mathrm{C}_{\mathrm{H} 2 \mathrm{O}} / \mathrm{GFR} / \mathrm{V}$ averaged $0.662 \pm 0.064$ during the control period and increased to $0.785 \pm$ 0.087 after insulin $(P<0.02)$.

Plasma aldosterone and glucagon. Plasma aldosterone concentration was low during the control period (Table $\mathrm{V}$ ), in keeping with the prior dietary salt loading and with water loading; aldosterone levels did not change significantly during insulin administration. Plasma glucagon concentration, which was $97 \pm 17 \mathrm{pg} / \mathrm{ml}$ in the control period, decreased to $74 \pm 14 \mathrm{pg} / \mathrm{ml}(P<0.02)$ during insulin administration. 
TABLE IV

Effect of Insulin on Plasma and Urine Osmolality $\left(U_{\text {osm }}\right)$, Urine Flow, Osmolar Clearance and Free Water Clearance

\begin{tabular}{|c|c|c|c|c|c|c|c|}
\hline Subject & Period & $P_{o s m}$ & $U_{o s m}$ & Urine flow & $\mathrm{Cosm}_{\mathrm{os}}$ & $\mathrm{C}_{\mathrm{H}_{2} \mathrm{O}}$ & $\mathrm{C}_{\mathrm{H}_{2} \mathrm{O} / \mathrm{C}_{I N} \times 100}$ \\
\hline \multirow{3}{*}{ I. B. } & & $\mathrm{mosmol} / \mathrm{kg}$ & $\mathrm{mosmol} / \mathrm{kg}$ & $\mathrm{ml} / \mathrm{min}$ & $\mathrm{ml} / \mathrm{min}$ & $\mathrm{ml} / \mathrm{min}$ & $\mathrm{ml} / \mathrm{min}$ \\
\hline & Control & $289 \pm 2$ & $65 \pm 4$ & $14.6 \pm 0.5$ & $3.3 \pm 0.3$ & $11.3 \pm 0.2$ & $14.2 \pm 0.3$ \\
\hline & Insulin & $292 \pm 2$ & $52 \pm 5$ & $13.7 \pm 0.9$ & $2.3 \pm 0.3$ & $11.4 \pm 0.7$ & $16.5 \pm 0.6$ \\
\hline \multirow{2}{*}{ R. M. } & Control & $284 \pm 1$ & $94 \pm 4$ & $14.8 \pm 1.0$ & $5.0 \pm 0.5$ & $10.0 \pm 1.1$ & $9.3 \pm 0.9$ \\
\hline & Insulin & $283 \pm 1$ & $51 \pm 1$ & $15.5 \pm 0.5$ & $2.8 \pm 0.1$ & $12.7 \pm 0.4$ & $13.6 \pm 0.8$ \\
\hline \multirow{2}{*}{ H. W. } & Control & $287 \pm 1$ & $136 \pm 14$ & $14.7 \pm 1.4$ & $6.8 \pm 1.6$ & $7.9 \pm 1.4$ & $7.6 \pm 1.3$ \\
\hline & Insulin & $291 \pm 1$ & $54 \pm 2$ & $17.1 \pm 0.9$ & $3.2 \pm 0.1$ & $13.9 \pm 0.8$ & $11.6 \pm 0.7$ \\
\hline \multirow{2}{*}{ G. B. } & Control & $284 \pm 1$ & $72 \pm 6$ & $17.0 \pm 0.3$ & $4.1 \pm 0.2$ & $11.7 \pm 1.2$ & $10.3 \pm 0.9$ \\
\hline & Insulin & $286 \pm 2$ & $44 \pm 2$ & $17.2 \pm 0.5$ & $2.7 \pm 0.2$ & $14.5 \pm 0.4$ & $12.0 \pm 0.6$ \\
\hline \multirow{2}{*}{ R. I). } & Control & $293 \pm 1$ & $94 \pm 1$ & $17.1 \pm 0.2$ & $5.5 \pm 0.2$ & $11.6 \pm 0.1$ & $10.6 \pm 0.1$ \\
\hline & Insulin & $294 \pm 1$ & $77 \pm 2$ & $18.3 \pm 0.3$ & $4.8 \pm 0.2$ & $13.6 \pm 0.1$ & $11.6 \pm 0.1$ \\
\hline \multirow{2}{*}{ P. D. } & Control & $288 \pm 1$ & $86 \pm 2$ & $16.2 \pm 0.6$ & $4.9 \pm 0.2$ & $11.3 \pm 0.3$ & $10.4 \pm 0.3$ \\
\hline & Insulin & $287 \pm 1$ & $71 \pm 1$ & $15.7 \pm 0.1$ & $3.9 \pm 0.1$ & $11.8 \pm 0.1$ & $11.5 \pm 0.1$ \\
\hline \multirow{2}{*}{ Mean \pm SEM } & Control & $287 \pm 1$ & $91 \pm 1$ & $15.7 \pm 0.5$ & $4.9 \pm 0.5$ & $10.6 \pm 0.6$ & $10.4 \pm 0.9$ \\
\hline & Insulin & $289 \pm 2$ & $\begin{array}{c}58 \pm 5 \\
(P<0.02)\end{array}$ & $16.3 \pm 0.7$ & $\begin{array}{c}3.3 \pm 0.4 \\
(P<0.01)\end{array}$ & $\begin{array}{c}13.0 \pm 0.5 \\
(P<0.02)\end{array}$ & $\begin{array}{c}12.8 \pm 0.8 \\
(P<0.01)\end{array}$ \\
\hline
\end{tabular}

\section{Control water diuresis studies}

Data from the control water diuresis studies $(5 \mathrm{~h}$ of sustained water diuresis and recumbency, but without insulin administration) performed on two of the six subjects are shown in Table VI. There were no changes in plasma sodium, potassium, calcium, and phosphate concentration; plasma osmolality remained constant. $\mathrm{U}_{\mathrm{Na}} \mathrm{V}$ increased slightly in one subject and was constant in the other. In subject P. D., $\mathrm{U}_{\mathrm{Ca}} \mathrm{V}$ and $\mathrm{U}_{\mathrm{K}} \mathrm{V}$ decreased slightly, while $U_{P V}$ increased moderately. There was no alteration in creatinine clearance, $\mathrm{C}_{\text {osm }}$ or $\mathrm{C}_{\mathrm{H}=\mathrm{O}}$. Urine flow decreased slightly in subject P. D.

\section{DISCUSSION}

These studies demonstrate an effect of insulin on urinary sodium excretion which is clearly independent of changes in the filtered load of glucose, GFR, renal blood flow, and plasma aldosterone concentration. Control subjects studied under similar conditions of water diuresis but without insulin administration showed no change in urinary sodium excretion during the 5-h study period. Thus, the reduction in sodium excretion noted during insulin administration cannot be attributed to diurnal variation or to the effects of prolonged water diuresis. The onset of this sodium-retaining effect occurred within 30 min after insulin administration was begun, reached statistical significance at $60 \mathrm{~min}$, and was maximal between $60-120 \mathrm{~min}$ (Fig. 1). The sodium-retaining effect of insulin was readily apparent at physiological concentrations of the hormone in blood (98-193 $\mu \mathrm{U} / \mathrm{ml})$. There was no correlation between the amount of glucose metabolized and changes in urinary sodium excretion.

Aldosterone secretion, as shown by the persistently low plasma aldosterone concentration, was suppressed in these studies both before and during the infusion of insulin. This suppression is attributed to the high dietary intake of sodium before study, to water loading during the study, and to the depression of plasma potassium concentration induced by insulin and glucose administration (35). Induction of sodium retention by insulin is therefore not dependent upon volume depletion or increased aldosterone secretion, factors that have made it difficult to interpret data from studies on diabetic patients who were treated with insulin after periods of interrupted therapy $(6,7)$. Previous studies $(37,38)$ 
have demonstrated a reduction in urinary sodium excretion after oral administration of glucose during a water diuresis. Since fractional glucose reabsorption and sodium excretion were negatively correlated in these studies, it was suggested that proximal tubular sodium reabsorption is facilitated by glucose reabsorption. This could not explain the increase in sodium reabsorption in our studies since filtered glucose and glucose reabsorption were unchanged.

While our data do not permit precise localization of the effect of insulin on sodium excretion, several findings suggest an action of insulin on sodium reabsorption in the distal nephron. The increase in $\mathrm{C}_{\mathrm{H}: \mathrm{O}}$ that occurred without an increase in urine volume $(\mathrm{V})$ is consistent with an effect of insulin on the diluting segment of the renal tubules. During water diuresis, the volume of urine excreted reflects the volume of filtrate remaining at the end of the proximal convoluted tubules, and $\mathrm{C}_{\mathrm{H}_{2} \mathrm{O}}$ is an index of sodium reabsorption in the distal nephron (39). Enhancement of sodium reabsorption in the proximal convoluted tubules would reduce the volume of urine excreted as well as the quantity of sodium delivered to the diluting segments, and $\mathrm{C}_{\mathrm{H}_{2} \mathrm{O}}$ would be reduced. In all six subjects studied there was no significant change in $\mathrm{V}$ or in $\mathrm{V} / \mathrm{C}_{1 \mathrm{x}} ; \mathrm{C}_{\mathrm{osm}}$ was decreased and $\mathrm{C}_{\mathrm{H}_{2} \mathrm{O}}, \mathrm{C}_{\mathrm{H}_{2} \mathrm{O}} / \mathrm{C}_{\mathrm{IN}}$, and $\mathrm{C}_{\mathrm{H}_{2} \mathrm{O}} / \mathrm{GFR} / \mathrm{V}$ were increased. These observations are consistent with an effect of insulin on sodium reabsorption in the distal nephron, i.e., the ascending limb of the loop of Henle and/or the distal convoluted tubules. The dissociation of calcium and sodium transport is also consistent with an effect of insulin on the distal nephron.

Whether insulin acts directly on sodium transport in renal tubules or through an indirect mechanism which increases energy supply to the sodium transport system cannot be inferred from the present studies. However, Benjamin, and Singer (40) recently have reported that both insulin and aldosterone increase sodium transport in the toad urinary bladder; this effect occurs in association with the induction of a low molecular weight protein. These observations lend support
TABLE V

Plasma Aldosterone and Glucagon Concentrations before and during Insulin Administration

\begin{tabular}{|c|c|c|c|}
\hline Subject & Period & $\begin{array}{l}\text { Plasma } \\
\text { aldosterone }\end{array}$ & $\begin{array}{c}\text { Plasma } \\
\text { glucagon }\end{array}$ \\
\hline \multirow{2}{*}{ L. B. } & Control & $\begin{array}{l}n g / 100 \mathrm{ml} \\
5.7 \pm 0.2\end{array}$ & $\begin{array}{r}p g / m l \\
162 \pm 4\end{array}$ \\
\hline & Insulin & $7.8 \pm 1.0$ & $122 \pm 16$ \\
\hline \multirow{2}{*}{ R. M. } & Control & $7.0 \pm 0.4$ & $97 \pm 5$ \\
\hline & Insulin & $6.6 \pm 0.3$ & $88 \pm 2$ \\
\hline \multirow{2}{*}{ H. W. } & Control & $7.7 \pm 0.5$ & $67 \pm 3$ \\
\hline & Insulin & $6.5 \pm 0.7$ & $53 \pm 2$ \\
\hline \multirow{2}{*}{ G. B. } & Control & $5.7 \pm 0.4$ & - \\
\hline & Insulin & $7.0 \pm 0.3$ & - \\
\hline \multirow{2}{*}{ R. D. } & Control & $3.6 \pm 0.2$ & $67 \pm 2$ \\
\hline & Insulin & $3.3 \pm 0.1$ & $48 \pm 2$ \\
\hline \multirow{2}{*}{ P. D. } & Control & $4.0 \pm 0.2$ & $92 \pm 5$ \\
\hline & Insulin & $4.1 \pm 0.1$ & $58 \pm 4$ \\
\hline \multirow{2}{*}{ Mean \pm SE.M } & Control & $5.6 \pm 0.7$ & $97 \pm 17$ \\
\hline & Insulin & $5.9 \pm 0.6$ & $\begin{array}{c}74 \pm 14 \\
(P<0.02)\end{array}$ \\
\hline
\end{tabular}

to an hypothesized direct effect of insulin on the renal tubule.

Recently, glucagon administered in pharmacologic doses has been shown to be natriuretic $(23,26)$. Because increases in plasma insulin concentration are known to be accompanied by reciprocal changes in circulating levels of glucagon (41), the possibility exists that lowering of endogenous glucagon concentration during our insulin infusion studies may have contributed to the antinatriuresis which was observed. There are no

TABLE VI

Effect of Sustained Water Diuresis on Creatinine Clearance $\left(C_{C^{r}}\right)$, Sodium, Potassium, Calcium and Phosphate Excretion, $V, C_{o s m}$, and $C_{H_{2} \mathrm{O}}$.

\begin{tabular}{|c|c|c|c|c|c|c|c|c|c|}
\hline Subject & Period & $\mathrm{C}_{\mathrm{Cr}}$ & $\mathrm{UNaV}_{\mathrm{a}}$ & $\mathrm{U}_{\mathrm{K}} \mathrm{V}$ & $\mathrm{UCaV}$ & $\mathrm{UPV}_{\mathrm{P}}$ & V & $\mathrm{C}_{\mathrm{n}+\mathrm{m}}$ & $\mathrm{C}_{\mathrm{H}_{2} \mathrm{O}}$ \\
\hline \multirow{3}{*}{ R. D. } & & $\mathrm{ml} / \mathrm{min}$ & $\mu e q / \min$ & $\mu e q / \min$ & $\mu g / m i n$ & $\mu g / \min$ & $m l / m i n$ & $\mathrm{ml} / \mathrm{min}$ & $\mathrm{ml} / \mathrm{min}$ \\
\hline & $0-120 \mathrm{~min}$ & $118 \pm 12$ & $187 \pm 6$ & $177 \pm 5$ & $49 \pm 9$ & $464 \pm 50$ & $12.4 \pm 0.1$ & $2.4 \pm 0.3$ & $9.9 \pm 0.4$ \\
\hline & $120-240 \mathrm{~min}$ & $117 \pm 8$ & $209 \pm 4$ & $191 \pm 2$ & $34 \pm 2$ & $456 \pm 23$ & $12.5 \pm 0.1$ & $2.2 \pm 0.1$ & $10.3 \pm 0.2$ \\
\hline \multirow{2}{*}{ P. D. } & $0-120 \mathrm{~min}$ & $136 \pm 5$ & $284 \pm 17$ & $69 \pm 2$ & $99 \pm 5$ & $172 \pm 29$ & $15.6 \pm 0.2$ & $3.2 \pm 0.4$ & $12.4 \pm 0.2$ \\
\hline & $120-240 \mathrm{~min}$ & $140 \pm 5$ & $263 \pm 9$ & $56 \pm 3$ & $80 \pm 2$ & $416 \pm 65$ & $14.4 \pm 0.3$ & $3.3 \pm 0.2$ & $11.1 \pm 0.5$ \\
\hline
\end{tabular}


currently available data to indicate, however, that increased levels of glucagon within the physiologically normal range increase sodium excretion or that small decreases are natriuretic. In our studies a small decrease in plasma glucagon concentration $(23 \mathrm{pg} / \mathrm{ml}$, Table V) occurred as expected during the period of hyperinsulinemia. Although this change was statistically significant, its physiologic implications with respect to sodium transport await further investigations.

Interdependence of sodium and calcium transport in the kidney was suggested by the studies of Walser (42) and others (43-47). Sodium and calcium reabsorption in the proximal convoluted tubules varies in close concert under a variety of conditions, suggesting either a common transport mechanism or dependence of calcium reabsorption on sodium reabsorption and related water reabsorption $(48,49)$. However, the interrelationship of distal sodium and calcium transport (49-54) appears to differ substantially from that of sodium and calcium transport in the proximal tubules. Studies involving the acute administration of adrenal steroids have shown a reciprocal relationship between sodium and calcium excretion which suggest that the reabsorption of these cations may be inversely correlated in the distal nephron $(48,55,56)$. Increased urinary calcium excretion has been observed after oral glucose loading ( 37 , $38,57,58)$, and our studies would imply that such an effect may be insulin mediated. Possible explanations for the increased calcium excretion in our studies include a direct inhibitory effect of insulin on calcium transport, an indirect inhibitory effect (mediated, for example, through changes in intracellular metabolites or $\mathrm{pH}$ : see references 37 and 59 ), or a reduction in level or activity of parathormone.

Insulin administration in our studies also affected the excretion of phosphate and potassium. $U_{P} V$ decreased significantly. The small decrease in plasma phosphate concentration which we observed was not uniform, but may have been sufficient to reduce the filtered phosphate load below the tubular reabsorptive capacity of phosphate, contributing in part to the large reduction in phosphate excretion. A decrease in parathormone effect on the kidney, by whatever mechanism, could also explain the change in $U_{r} V$.

Plasma potassium concentration decreased during insulin administration, concomitant with a presumed net influx of potassium into liver and skeletal muscle (6062). Urinary potassium also decreased, but the latter observation cannot be attributed to the reduction in filtered load of potassium associated with decreased plasma potassium concentration, since the rate of potassium excretion is determined largely, if not solely, by potassium secretion (63-65). Likewise, decreased distal tubule delivery of sodium, reflecting increased sodium reabsorption, cannot account for this finding because the quantity of sodium excreted during insulin administration indicates that sufficient sodium remained available for exchange with potassium at the site of potassium secretion (64).

There is no data available describing the effect of insulin administration on the intracellular potassium content of the renal tubules, and whether the renal tubular cells share in the augmented influx of potassium induced by insulin in other tissues is unknown. Malnic, Mello-Aires, and Giebish (66) have shown that potassium excretion relates to the plasma potassium to the extent that the plasma level reflects intracellular potassium content. Thus, one might expect the reduction in potassium excretion produced by insulin to be associated with a reduction in the potassium content of the renal tubular cells. No direct effect of insulin on the net uptake of potassium by renal tubule cells would be required to produce this effect, since the reduction in plasma potassium concentration can be attributed to enhanced potassium uptake by the liver and skeletal muscle. If, on the other hand, insulin actually increases potassium transport into tubular cells, our data would be compatible with either an inhibitory effect of insulin on potassium secretion or an increase of intracellular potassium in a compartment that has no effect on potassium secretion (67).

Additional studies are required to determine the mechanism of reduction in potassium excretion as well as the changes in sodium, calcium, and phosphate excretion induced by insulin administration. In the case of sodium and potassium excretion, the changes induced by insulin are similar to those observed in fasted obese subjects during carbohydrate refeeding (9-15). The possibility that insulin plays a role in the excessive retention of sodium that accompanies carbohydrate refeeding in fasted subjects was suggested by the studies of Kolanowski et al. (18). These investigators also infused insulin without glucose into fasting obese subjects and observed no reduction in sodium excretion. However, the hypoglycemia which resulted may have obscured the effect of insulin on the renal handling of sodium by stimulating glucagon secretion as well as other counterregulatory mechanisms which would oppose sodium retention (17).

The effects on sodium excretion of glucose refeeding to fasted subjects has been assessed by calculating $\mathrm{V} /$ GFR and $\mathrm{C}_{\mathrm{H}_{2} \mathrm{O}} / \mathrm{V}$ as indices of proximal and distal tubular sodium reabsorption, respectively $(10,68)$. Schloeder and Stinebaugh (68) found decreased V/ GFR and increased $\mathrm{C}_{\mathrm{H}: \mathrm{O}} / \mathrm{V}$ during glucose administration, suggesting that both proximal and distal sodium 
reabsorption were enhanced. Hoffman, Martino, Wahl, and Arky (10) reported that during glucose refeeding a decrease in $\mathrm{V} / \mathrm{GFR}$ occurred, indicating increased proximal tubular sodium reabsorption, whereas no change occurred in $\mathrm{C}_{\mathbf{H} 2 \mathrm{O}} / \mathrm{V}$; the subjects were not examined for glucosuria, a factor during glucose loading which may affect $\mathrm{C}_{\mathrm{H}: \mathrm{O}} / \mathrm{V}$. In contrast to both of these studies, our glucose administration protocol held blood glucose at the fasting level and was not intended to bear directly on the phenomenon of refeeding antinatriuresis. Our data do suggest that the fall in V/ GFR observed during glucose refeeding by Hoffman et al. (10) is not related to the rise in circulating levels of insulin which accompanies glucose administration; any changes in $\mathrm{V} / \mathrm{GFR}$ which occur must be secondary to other factors such as a fall in plasma glucagon or the altered energy availability in the kidney. On the other hand, the increased $\mathrm{C}_{\mathbf{H}: \mathrm{O}} / \mathrm{V}$ observed by Schloeder and Stinebaugh (68) in their glucose refeeding studies, and which was seen in our own studies during glucose administration, may reflect action of insulin on the distal nephron.

\section{ACKNOWLEDGMENT}

This work was supported in part by U. S. Public Health Service Research Grant HL-03303.

\section{REFERENCES}

1. Herrera, F. C., G. Whittembury, and A. Planchart. 1963. Effect of insulin on short-circuit current across isolated frog skin in the presence of calcium and magnesium. Biochim. Biophys. Acta. 66: 170-172.

2. Andre, R., and J. Crabbé. 1966. Stimulation by insulin of active sodium transport by toadskin: influence of aldosterone and vasopressin. Arch. Int. Physiol. Biochim. 74 : 538-540.

3. Crabbé, J., and B. Francois. 1967. Stimulation par l'insuline du transport actif de sodium a travers les membranes epitheliales du crapaud, Bufo marinus. Ann. Endocrinol. 28: 713-715.

4. Francois, B., M. deGasparo, and J. Crabbé. 1969. Interaction between isolated amphibian skin and insulin. Arch. Int. Physiol. Biochim. 77: 527-530.

5. Nizet, A., P. Lefebvre, and J. Crabbé. 1971. Control by insulin of sodium, potassium, and water excretion by the isolated dog kidney. Pflucgers Arch. Eur. J. Phy'siol. 323: 11-20.

6. Atchley, D. W., R. F. Loeb, D. W. Richards, Jr., E. M. Benedict, and M. E. Driscoll. 1933. J. Clin. Invest. 12 : 297-326.

7. Saudek, C. D., P. R. Boulter, R. H. Knopp, and R. A. Arky. 1974. Sodium retention accompanying insulin treatment of diabetes mellitus. Diabctcs. 23: 240-246.

8. Miller, J. H., and M. D. Bogdonoff. 1954. Antidiuresis associated with administration of insulin. J. Appl. Phy'siol. 6 : 509-512.

9. Veverbrants, E., and R. A. Arky. 1969. Effects of fasting and refeeding. I. Studies on sodium, potassium, and water excretion on a constant electrolyte and fluid intake. J. Clin. Endocrinol. Mctab. 29: 55-62.

10. Hoffman, R. S., J. A. Martino, G. Wahl, and R. A. Arky. 1969. Effects of fasting and refeeding. II. Tubular sites of sodium reabsorption and effects of oral carbohydrate on potassium, calcium, and phosphate excretion. J. Lab. Clin. Mcd. 74: 915-926.

11. Hoffman, R. S., J. A. Martino, G. Wahl, and R. A. Arky. 1971. Fasting and refeeding. III. Antinatriuretic effect of oral and intravenous carbohydrate and its relationship to potassium excretion. Mctab. (Clin. Exp.). 20: $1065-1073$.

12. Bloom, W. L. 1973. Salt excretion of fasting patients. Arch. Intcrn. Mcd. 106: 321-326.

13. Bloom, W. L. 1962. Inhibition of salt excretion by carbohydrate. Arch. Intcrn. Mcd. 109: 26-32.

14. Katz, A. I., D. R. Hollingsworth, and F. H. Epstein. 1968. Influence of carbohydrate and protein on sodium excretion during fasting and refeeding. J. Lab. Clin. Mcd. 72: 93-104.

15. Gersing, A., and W. W. Bloom. 1962. Glucose stimulation of salt retention in patients with aldosterone inhibition. Mctab. (Clin. Exp.). 11: 329-336.

16. Rapoport, A., G. I. A. From, and H. Husdan. 1965. Metabolic studies in prolonged fasting. I. Inorganic metabolism and kidney function. Mctab. (Clin. Exp.). $14: 31-46$.

17. Kolanowski, J., M. deGasparo, P. Desmecht, and J. Crabbé. 1972. Further evaluation of the role of insulin in sodium retention associated with carbohydrate administration after a fast in the obese. Eur. J. Clin. Invest. 2 : 439-444.

18. Kolanowski, J., M. A. Pizarro, M. deGasparo, P. Desmecht, C. Harvengt, and J. Crabbé. 1970. Influence of fasting on adrenocortical and pancreatic islet response to glucose loads in the obese. Eur. J. Clin. Invest. 1: $25-31$.

19. Wright, H. K., D. S. Gann, and K. Albertsen. 1963. Effect of glucose on sodium excretion and renal concentrating ability after starvation in man. Mctab. (Clin. Exp.). 12: 804-811.

20. Cooke, C. R., A. Whelton, and W. G. Walker. 1967. Paradoxical sodium retention in the presence of falling aldosterone secretion. Clin. Res. 15: 49. (Abstr.)

21. Marliss, E. B., T. T. Aoki, R. H. Unger, J. S. Soeldner, and G. F. Cahill, Jr. 1970. Glucagon levels and metabolic effects in fasting man. J. Clin. Invest. 49: 22562270.

22. Saudek, C. D., P. R. Boulter, and R. A. Arky. 1973. The natriuretic effect of glucagon and its role in starvation. J. Clin. Endocrinol. Mctab. 36: 761-765.

23. Staub, A., V. Springs, F. Stool, and H. Elrick. 1957. A renal action of glucagon. Proc. Soc. Exp. Biol. Mcd. 94: $57-60$.

24. Elrick, H., E. R. Huffman, C. J. Hlad, Jr., N. Whipple, and A. Staub. 1958. Effects of glucagon on renal function in man. J. Clin. Endocrinol. Mctab. 18: 813-824.

25. Levy, M., and N. L. Stark. 1972. The mechanism of glucagon-induced natriuresis in dogs. Kidncy Int. 2: 7684.

26. Pullman, T. N., A. R. Lavender, and I. Alto. 1967. Direct effects of glucagon on renal hemodynamics and excretion of inorganic ions. Mctab. (Clin. Exp.). 16: 358-373. 
27. Sherwin, R. S., K. J. Kramer, J. D. Tobin, P. A. Insel, J. E. Liljenquist, M. Berman, and R. Andres. 1974. A model of the kinetics of insulin in man. J. Clin. Invest. 53 : 1481-1492.

28. Andres, R. 1971. Aging and diabetes. Med. Clin. North Am. 55: 835-846.

29. Trudeau, D. L., and E. F. Freier. 1967. Determination of calcium in urine and serum by atomic absorption spectrophotometry (AAS). Clin. Chem. 13: 101-114.

30. Fiske, C. H., and Y. Subbarow. 1925. The colorimetric determination of phosphorus. J. Biol. Chem. 66: 375386.

31. Harvey, R. B., and A. J. Brothers. 1962. Renal extraction of paraaminohippurate and creatine measured by continuous in vivo sampling of arterial and renalvein blood. Ann. N. Y. Acad. Sci. 102: 46-54.

32. Hawk, P. B., B. L. Oser, and W. H. Summerson. 1954. Practical Physiological Chemistry. The Blakiston Company, Inc., New York. 13th edition. 555-558.

33. Walser, M., D. G. Davidson, and J. Orloff. 1955. The renal clearance of alkali-stable inulin. J. Clin. Invest. $34: 1520-1523$.

34. Yalow, R. S., and S. A. Berson. 1960. Immunoassay of endogenous plasma insulin in man. J. Clin. Invest. $39: 1157-1175$.

35. Cooke, C. R., J. S. Horvath, M. A. Moore, T. Bledsoe, and W. G. Walker. 1973. Modulation of plasma aldosterone concentration by plasma potassium in anephric man in the absence of a change in potassium balance. J. Clin. Invest. 52 : 3028-3032.

36. Faloona, G. R., and R. H. Unger. 1974. Glucagon. In Methods of Hormone Radioimmunoassay. B. M. Jaffe and H. R. Behrman, editors. Academic Press, Inc., New York. 317-330.

37. Lennon, E. J., and W. F. Piering. 1970. A comparison of the effects of glucose ingestion and $\mathrm{NH}_{4} \mathrm{Cl}$ acidosis on urinary calcium and magnesium excretion in man. J. Clin. Invest. 49 : 1458-1465.

38. Lennon, E. J., J. Lemann, Jr., W. F. Piering, and L. S. Larson. 1974. The effect of glucose on urinary cation excretion during chronic extracellular volume expansion in normal man. J. Clin. Invest. 53: 14241433.

39. Eknoyan, G., W. N. Suki, F. C. Rector, and D. W. Seldin. 1967. Functional characteristics of the diluting segment of the dog nephron and the effect of extracellular volume expansion on its reabsorptive capacity. J. Clin. Invest. 46: 1178-1188.

40. Benjamin, W. B., and I. Singer. 1974. Aldosterone and insulin induced proteins. Clin. Res. 22: 516. (Abstr.)

41. Unger, R. 1971. Glucagon physiology and pathophysiology. N. Engl. J. Med. 285: 443-449.

42. Walser, M. 1961. Calcium clearance as a function of sodium clearance in the dog. Am. J. Physiol. 200: 10991104.

43. Wesson, L. G., Jr. 1962. Magnesium, calcium, and phosphate excretion during osmotic diuresis in the dog. J. Lab. Clin. Med. 60: 422-432.

44. Massry, S. G., J. W. Coburn, L. W. Chapman, and C. R. Kleeman. 1967. Effect of $\mathrm{NaCl}$ infusion on urinary $\mathrm{Ca}^{++}$and $\mathrm{Mg}^{++}$during reduction in their filtered loads. Am. J. Physiol. 213: 1218-1224.

45. Blythe, W. B., H. J. Gitelman, and L. G. Welt. 1968. Effect of expansion of the extracellular space on the rate of the urinary excretion of calcium. Am. J. Physiol. $214: 52-57$.

46. Kleeman, C. R., J. Bohannan, D. Bernstein, S. Ling, and M. H. Maxwell. 1964. Effect of variation in sodium intake on calcium excretion in normal humans. Proc. Soc. Exp. Biol. Med. 115 : 29-32.

47. Parfitt, A. M. 1969. The acute effects of mersalyl, chlorothiazide, and mannitol on the renal excretion of calcium and other ions in man. Clin. Sci. (Oxf.). 36: 267-282.

48. Walser, M. 1971. Calcium-sodium interdependence in renal transport. In Renal Pharmacology. J. W. Fisher and E. J. Cafrumy, editors. Appleton-Century-Crofts, Inc., New York. 21-41.

49. Schneider, E. G., J. W. Strandhoy, L. R. Willis, and F. G. Knox. 1973. Relationship between proximal sodium reabsorption and excretion of calcium, magnesium, and phosphate. Kidney Int. 4: 369-376.

50. Beck, L. H., and Goldberg, M. 1973. Effects of acetazolamide and parathyroidectomy on renal transport of sodium, calcium, and phosphate. Am. J. Physiol. 224: 1336-1142.

51. Lassiter, W. E., C. W. Gottschalk, and M. Mylle. 1963. Micropuncture study of renal tubular reabsorption of calcium in normal rodents. Am. J. Physiol. $204:$ 771-775.

52. Howard, P. J., W. S. Wilde, and R. L. Malvin. 1959. Localization of renal calcium transport: effect of calcium loads and of gluconate anion on water, sodium, and potassium. Am. J. Physiol. 197: 337-341.

53. Samiy, A. H. E., J. L. Brown, D. L. Globus, R. H. Kessler, and D. D. Thompson. 1960. Interrelation between renal transport systems of magnesium and calcium. Am. J. Physiol. 198: 599-602.

54. Grollman, A. P., W. G. Walker, H. C. Harrison, and H. E. Harrison. 1963. Site of reabsorption of citrate and calcium in the renal tubule of the dog. Am. J. Physiol. 205: 697-701.

55. Robinson, B. H. B., E. B. Marsh, Jr., J. W. Duckett, and M. Walser. 1962. Adrenocortical modification of the interdependence of calcium and sodium reabsorption in the kidney. J. Clin. Invest. 41: 1394. (Abstr.)

56. Massry, S. G., J. W. Coburn, L. W. Chapman, and C. R. Kleeman. 1967. The acute effect of adrenal steroids on the interrelationship between the renal excretion of sodium, calcium, and magnesium. J. Lab. Clin. Med. 70: 563-570.

57. Lindeman, R. D., S. Adler, M. J. Yiengst, and E. S. Beard. 1967. Influence of various nutrients on urinary divalent cation excretion. J. Lab. Clin. Med. 70: 236245.

58. Boner, G., M. Newton, and R. E. Rieselboch. 1973. Exaggerated carbohydrate-induced calciuria in the remaining kidney of transplant donors. Kidney Int. 3: 24-29.

59. Poole, D. J. 1967. Intracellular $\mathrm{pH}$ of the Ehrlich ascites tumor cell as it is affected by sugars and sugar derivatives. J. Biol. Chem. 242: 3731-3736.

60. Fineberg, S. E., and T. J. Merimee. 1973. Effects of comparative perfusions of equimolar, single component insulin, and proinsulin in the human forearm. Diabetes. 22 : $676-686$

61. Andres, R., M. A. Baltzan, G. Cader, and K. L. Zierler. 1962. Effect of insulin on carbohydrate metabolism 
and on potassium in the forearm of man. J. Clin. Invest. 41 : 108-115.

62. Fenn, W. O. 1939. The deposition of potassium and phosphate with glycogen in rat livers. J. Biol. Chem. 128: 297-307.

63. Malnic, G., R. M. Klose, and G. Giebish. 1964. Micropuncture study of renal potassium excretion in the rat. Am. J. Physiol. 206: 674-686.

64. Malnic, G., R. M. Klose, and G. Giebish. 1966. Micropuncture study of distal tubular potassium and sodium transport in the rat nephron. Am. J. Physiol. 211: 529547.
65. Brenner, B. M., and R. W. Berliner. 1973. The transport of potassium. Handb. Physiol. (Sect. 8) : 497-519.

66. Malnic, G., M. Mello-Aires, and G. Giebish. 1971. Potassium transport across renal distal tubule during acidbase disturbances. Am. J. Physiol. 221: 1192-1208.

67. Wiederholt, M., W. J. Sullivan, and G. Giebisch. 1971. Potassium and sodium transport across single distal tubules of Amphiuma. J. Gen. Physiol. 57: 495-525.

68. Schloeder, F. X., and Stinebaugh, B. J. 1970. Renal tubular sites of natriuresis of fasting and glucose-induced sodium conservation. Metab. (Clin. Exp.). 19: 11191128. 